\title{
The capability of early detection of eye diseases in the community by primary health facility worker
}

\author{
Doni Widyandana, ${ }^{*}$ Mohammad Eko Prayogo, and Suhardjo
}

Department of Ophthalmology, Faculty of Medicine, Public Health, and Nursing, Universitas Gadjah Mada, Yogyakarta, Indonesia

SUBMITTED: 6 February 2019

REVISED: 23 May 2019

ACCEPTED: 9 July 2019

KEYWORDS

Early detection

Eye disease

Primary health

facilities

\begin{abstract}
Cataract is one of the biggest causes of blindness in the world. As many as 2.4 million people suffered from cataracts in Indonesia in 2013. Therefore, early detection needs to be done to prevent further complications. However, health workers' limited ability in primary health care facilities has resulted in high cataract diagnosis rates. The purpose of this study was to determine the ability of early detection of eye diseases, especially cataracts by primary health care workers. This study was conducted using a quantitative descriptive method analyzing 158 medical records as a result of early detection of primary health care facilities in Sleman Regency, which were sent to the ophthalmologist team of the Department of Eye Health FK-KMK UGM to be re-examined. The re-examination results by a team of ophthalmologists received 141 medical records that fulfilled the inclusion criteria, consisting of 61 patients confirmed by cataract diagnosis (43.3\%) and 80 patients with a diagnosis of not cataract $(56.7 \%)$. According to the study, primary health care workers' ability towards early detection of cataracts in Sleman Regency needed to be enhanced (4.3\%).
\end{abstract}

(c) The Journal 2020. This article is distributed under a Creative Commons Attribution-ShareAlike 4.0 International license.

\section{Introduction}

Cataracts are the leading cause of blindness globally and the second cause of visual disturbances, accounting for $33.4 \%$ and $18.4 \%$, respectively. More than $40 \%$ of this number came from developing countries such as South Asia and Southeast Asia. ${ }^{1}$ In the fifteen provinces of Indonesia, the percentage of the leading causes of blindness is cataract. A cataract is counted as $70-80 \%$ as a cause of blindness, while other visual disturbances are $10-15 \% .^{2}$ This number is expected to increase continually in line with the increasing number of older people globally.

United Nations predicts that the world's population aged more than 60 years will increase by $56 \%$. Around 901 million people in 2015 and will become 1.4 billion people in 2030. ${ }^{3}$ For anticipating, the Indonesian Ministry of Health launched a road map program for overcoming visual impairment

\footnotetext{
*Correspondence: widyandana@ugm.ac.id

Department of Ophthalmology, Faculty of Medicine, Public Health, and Nursing, Universitas Gadjah Mada, Jl. Farmako, Sekip Utara, 55281, Yogyakarta, Indonesia
}

2017-2030. ${ }^{2}$ This program aims to overcome visual impairment for the realization of Indonesian people with healthy eyes by 2030 . The strategy initiated by the Ministry of Health is to increase the number of early detection and optimal cataract surgery, encourage each region to implement cataract control, and strengthen the tiered referral system from primary health facilities. ${ }^{2}$

Primary health care workers' ability to detect cataracts from an early age will determine the program's success. One of the program's obstacles is the gap in facilities and human resources in each primary health facility. Resource gaps lead to frequent misdiagnosis of cataracts by primary health workers. There is still an opportunity to improve through training on recognizing signs and symptoms of eye diseases for health workers. This study aims to determine the percentage of eye diseases in the community that interferes with vision and sees patterns of misdiagnosis of eye diseases by primary health care workers. 


\section{Method}

This research is a quantitative descriptive study, using secondary data from 158 medical records from early detection of primary healthcare workers included by random sampling method. From 158 medical records of referred patients, 17 patients were excluded due to incomplete data.

In this study, early detection was used to find cataract patients by primary health care officers. The patient was then referred to an ophthalmologist at the Department of Eye Health, Sardjito General Hospital (SGH) and Faculty of Medicine, Public Health, and Nursing Universitas Gadjah Mada (UGM) to be re-examined. Primary health facility officers who carry out early detection consist of general practitioners, nurses, and other health workers. The working area of this research is all Puskesmas in the Sleman region, which send patient medical record data to the ophthalmologist team of SGH and - Faculty of Medicine, Public Health, and Nursing UGM. From the patient's medical records, the results of early detection were re-checked by the ophthalmologist team SGH to record each patient's eye disease. Then the data were grouped into 2 . The first is the group diagnosed with cataracts, and the second is the group diagnosed with non-cataracts. Incomplete medical records or patients who were not cooperative to be examined were included in the exclusion criteria. This study's subject was the medical records of patients with eye diseases referred to by primary health care workers.

The identity and data of patients in medical records are kept confidential under the ethics code. Ethical clearance is issued by the Ethical Committee of Faculty of Medicine, Public Health, and Nursing UGM with letter number Ref: KE / FK / 0977 / EC / 2017. Data analysis was performed using quantitative descriptive analysis.

\section{Result}

After re-examination by ophthalmologists and residents, 141 medical records were obtained that met the inclusion criteria, with a diagnosis consisting of 61 patients confirmed with a cataract diagnosis $(43.3 \%)$ and 80 patients with a non-cataract diagnosis (56.7\%) (Table 1).
Table 1. Percentage of patients with eye disease sent by primary care worker $(n=141)$

\begin{tabular}{ll}
\hline Diagnose & $\mathbf{n}(\%)$ \\
\hline Cataract & $61(43.3)$ \\
Non-cataract & $80(56.7)$ \\
\hline
\end{tabular}

Based on Table 2, $56.7 \%$ of patients with a noncataract diagnosis, which is $35 \%$ were diagnosed with refractive disorders, $20 \%$ corneal abnormalities, $16.25 \%$ retinal and vitreous disorders, $12.5 \%$ eyelid disorders, $7.5 \%$ glaucoma, $6.25 \%$ eye nerve disorders, and the rest were diagnosed with emmetrope and sclera hyperpigmentation, respectively $1.25 \%$.

\section{Discussion}

In this study, out of a total of 158 patients referred for mass cataract surgery, 17 patients were excluded because the diagnosis was not listed so that 141 medical records were obtained with a diagnosis consisting of 61 patients confirmed with a cataract diagnosis (43.2\%) and 80 patients with a non-cataract diagnosis. (56.7\%). It shows that the accuracy of early detection of cataracts by health workers in primary health facilities is still very low (43.2\%). Based on the National Health System, problems in the quality of human health resources are inadequate numbers of personnel, the ratio of health workers to population is still low, the distribution of health workers is not optimal, and the quality of health workers. ${ }^{4}$

The uneven distribution of general practitioners resulted in the handling of patients often carried out by incompetent medical personnel, so that the examination results were considered inaccurate. ${ }^{5}$ The ability to manage diseases by doctors in primary health facilities in Indonesia is also considered lower than the 2006 Competency Standards for Indonesian Doctors (CSID). ${ }^{6}$ From this study, the ability of general practitioners to manage disease independently is only around $15.5-55.5 \%$ of 155 in the 2006 CSID case. It shows that limitations in mastering competence and understanding the concept of primary health facilities as a promotive and preventive function are still crucial problems in Indonesia. Therefore, additional education is needed for health workers in primary health facilities. ${ }^{7,8}$

Based on the Clinical Practice Guidelines for 
Table 2. Percentage of patients with a non-cataract diagnosis $(n=80)$

\begin{tabular}{lll}
\hline Category & Diagnosis & $\mathbf{N}(\%)$ \\
\hline Refractive disorders & Presbyopia & $20(25.00)$ \\
& Myopia & $2(2.50)$ \\
& High myopia & $3(3.75)$ \\
& Low vision & $1(1.25)$ \\
& Astigmatism compositus & $1(1.25)$ \\
& Anisometropia & $1(1.25)$ \\
\hline Corneal disorder & Pterygium & $13(16.25)$ \\
& Leukoma & $2(2.50)$ \\
\hline Retinal and vitreous disease & Cornea ulcer & $1(1.25)$ \\
& Floaters & $5(6.25)$ \\
& Retinopathy & $2(2.50)$ \\
& Diabetic retinopathy & $2(2.50)$ \\
& Suspect of hypertensive retinopathy & $2(2.50)$ \\
& Macular scars & $1(1.25)$ \\
& Age-related macular degeneration & $1(1.25)$ \\
\hline Eyelid disorder & Ptosis & $1(1.25)$ \\
& Blepharitis seborrheic & $1(1.25)$ \\
& Entropion & $1(1.25)$ \\
& Dry eye & $7(8.75)$ \\
\hline Glaucoma & Glaucoma & $6(7.50)$ \\
\hline Nerve problems & Postherpetic neuralgia & $1(1.25)$ \\
& Atrophy pupil & $2(2.50)$ \\
& Nystagmus & $1(1.25)$ \\
& Exstrophy & $1(1.25)$ \\
\hline & Emmetropia & $1(1.25)$ \\
\hline & Sclera hyperpigmentation & $1(1.25)$ \\
\hline & & \\
\hline
\end{tabular}

Doctors in First Level Health Care Facilities, cataract diagnosis can be made by clinical diagnosis through physical examination and simple support, including visual examination, shadow test, and there was lens opacity using an ophthalmoscope. ${ }^{9}$ The trial frame for checking refraction, Ishihara test book, trial lens for refraction examination, binocular loop 3-5 dioptres, direct ophthalmoscope, Snellen Chart type E Chart and Alphabet Chart, Schiotz tonometer, and Tumbling E-card are standard equipment that must be available at primary health care facilities as regulated in Regulation of the Minister of Health of the Republic of Indonesia (PERMENKES) No. 29 of 2016. ${ }^{10}$

Regarding the workforce, PERMENKES No. 29 years 2016 also states that doctors, nurses, and optometry services can be provided as collaboration partners in primary health care facilities. ${ }^{10}$ Therefore, cataract early detection training for all levels of health care workers in primary health care facilities is expected to be able to improve the ability of officers to 1) know the signs and symptoms of cataracts, 2) conduct a physical examination of the eye for cataract diagnosis, 3) write the results of the examination and the appropriate diagnosis, and 4) know patient reporting and service flow to access cataract surgery. ${ }^{11}$ In order to achieve this goal, the preparation of training materials can be done based on the identification of training needs in general for target groups who have the same characteristics or what is called a deductive approach model. ${ }^{12}$ It takes support from all health personnel in primary health facilities and adequate funding from stakeholders so that this program can run well.

Some of the deficiencies in this study include using secondary data so that researchers do not directly see the cataract screening process. Medical personnel who perform screening also cannot be directly assessed and only concluded based on written reports. Further research is needed to evaluate medical personnel who screen for cataracts and their competence and authority in conducting this screening.

\section{Conclusion}

In conclusion, the accuracy level of the early detection 
ability of eye diseases, especially cataracts, by primary health care workers in the Sleman Regency still needs to be improved. This research data can be used as a basis for developing training programs for primary health care workers as well as composting programs for the community regarding eye diseases.

\section{Acknowledgement}

The authors would like to thank the Department of Medical Education, Faculty of Medicine, Public Health, and Nursing UGM; Department of Ophthalmology Faculty of Medicine, Public Health, and Nursing UGM, and Indonesian Ophthalmologist Association of Yogyakarta for supporting this research process, as well as Helena Anindya Bintang Putri Weto who helped process data.

\section{Conflict of interest}

There is no conflict of interest

\section{References}

1. Khairallah $M$, Kahloun $R$, Bourne R, Limburg $H$, Flaxman SR, Jonas JB, et al., Number of people blind or visually impaired by cataract worldwide and in world regions, 1990 to 2010. Invest Ophthalmol Vis Sci. 2015;56(11):6762-9.

2. Kementerian Kesehatan Republik Indonesia. Menkes luncurkan peta jalan penanggulangan gangguan penglihatan. [Internet] Published October 12, 2017. Citate 10 December 2018. Available from: https://www.kemkes.go.id/ article/view/17101200004/menkes-luncurkanpeta-jalan-penanggulangan-gangguanpengelihatan.html

3. United Nations, D.o.E.a.S.A., Population Division. Department of Economic and Social Affairs, Population Division. World Population Ageing. [Internet] cited January 12, 2019; Available from: http://www.un.org/en/development/desa/ population/publications/pdf/ageing/WPA2015_ Report.pdf .

4. Adisasmito W. Sistem Kesehatan Nasional. 2007. Jakarta: PT. Rajagrafindo Persada.

5. Sukindar S. Perlindungan hukum terhadap perawat yang bertugas tanpa pendampingan dokter di puskesmas pembantu. Dedikasi.
2016;35(2):144-154.

6. Action $\mathrm{W}$, Claramita $\mathrm{M}$, Ekawati $\mathrm{FM}$, Gayatri A, Sutomo $A H$, Kusnanto $H$, et al. Physician's self-perceived abilities at primary care settings in Indonesia. J Family Med Prim Care. 2015;4(4):551-8.

7. Handayani L, Ma'ruf NA, Sopacua E. Peran tenaga kesehatan sebagai pelaksana pelayanan kesehatan puskesmas. Buletin Penelitian Sistem Kesehatan. 2010;13(1):12-20.

8. Weto HABP. Pola kesalahan diagnosis oleh petugas fasilitas kesehatan primer pada skrining bakti sosial katarak Kabupaten Sleman. 2018. Universitas Gadjah Mada.

9. Ikatan Dokter Indonesia. Panduan Praktik Klinis. 2017.

10. Kementerian Kesehatan Republik Indonesia. 2016. Peraturan Menteri Kesehatan Republik Indonesia No. 29 Tahun 2016 Tentang Penyelenggaraan Pelayanan Kesehatan Mata di Fasilitas Pelayanan Kesehatan.

11. Sulastri S. Peningkatan kapasitas kader kesehatan dalam mendeteksi katarak di Kecamatan Jatinangor Kabupaten Sumedang. Dharmakarya. 2018;7(1).

12. Kamil M. 2003. Model-model pelatihan. Bandung: UPI. 